\title{
Vegetation and deer response to mechanical shrub clearing and burning
}

\author{
JAMES O. ROGERS, TIMOTHY E. FULBRIGHT, AND DONALD C. RUTHVEN, III
}

Authors are Rangeland Management Specialist, Natural Resources Conservation Service, United States Department of Agriculture, Pearsall, Tex. 78061; Regent's Professor and Meadow's Professor, Caesar Kleberg Wildlife Research Institute, MSC 218, Texas A\&M University-Kingsville, Kingsville, Tex. 78363; and Natural Resource Specialist and Assistant Area Manager, Texas Parks and Wildlife Department, Chaparral Wildlife Management Area, P.O. Box 115, Artesia Wells, Tex. 78001.

\section{Abstract}

Prescribed burning is a recommended maintenance treatment following mechanical treatments of south Texas brushlands, but it is unknown whether it is preferable to additional mechanical treatments to improve habitat for white-tailed deer (Odocoileus virginianus Raf.). We tested the hypotheses that prescribed burning of aerated (top-growth removal of woody plants) plots during late summer would decrease protein-precipitating tannins in browse, increase forb biomass, and increase deer utilization compared to a second aeration. Ten patches of brush, ranging in size from 2.8-8.1 ha, were aerated during spring 1999. In late summer 2000, maintenance treatments were applied; 5 patches were burned and 5 were aerated a second time. Standing crop, nutritional quality, and tannin concentrations (browse only) of deer forages were estimated. Deer tracks crossing bulldozed lanes surrounding each patch were counted to estimate deer use. Standing crop of browse, forbs, grass, succulents, protein-precipitating tannins in browse, and track density did not differ between treatments. Based on deer use and forage biomass response, burning and a second aeration 16-17 months following an initial aeration appear to have similar effects on habitat characteristics and use of cleared patches by white-tailed deer. Because of lower cost, we recommended prescribed burning as a maintenance treatment of aerated shrublands.

Key Words: aeration, brush, brush management, forbs, maintenance treatments, Odocoileus virginianus, prescribed burning, white-tailed deer

Dense stands of woody plants provide diurnal cover for whitetailed deer (Odocoileus virginianus Raf.) (McMahan and Inglis 1974, Walsh 1985). However, yield and availability of forage, particularly herbaceous vegetation, is often low in dense shrub communities (Rollins and Bryant 1986). Top removal of shrubs promotes new browse growth and increases browse availability (Chamrad 1966). Woody plant resprouts following top removal are temporarily higher in crude protein, phosphorous $(\mathrm{P})$, and

At the time of research, Rogers was a graduate research assistant, Caesar Kleberg Wildlife Research Institute, MSC 218, Texas A\&M UniversityKingsville, Kingsville, Texas 78363.

Research was funded by the Texas Parks and Wildlife Department, Houston Livestock Show and Rodeo, Caesar Kleberg Foundation for Wildlife Conservation, and Ed Rachal Foundation. This is Caesar Kleberg Wildlife Research Institute Manuscript number 03-108.

Manuscript accepted 4 Mar. 03.

\section{Resumen}

El uso de quemas prescritas como tratamiento de mantenimiento es recomendable cuando se realizan tratamientos mecánicos en los matorrales del sur de Texas, sin embargo, se desconoce la conveniencia de realizar tratamientos mecánicos adicionales para mejorar el hábitat de venado cola blanca (Odocoileus virginianus Raf.).La hipótesis evaluada fué que la quema prescrita de áreas tratadas con el aereador de suelo (remoción de la cubierta vegetal de plantas leñosas) al final del verano reduciría el contenido de taninos ligados a proteínas en el ramoneo, incrementando producción de forraje de herbaceas y la utilización por venado cola blanca comparado con un segundo tratamiento de aereación. El tratamiento con el aereador de suelo se aplico en diez areas de entre 2.8 y 8.1 ha durante la primavera de 1999. Al final del verano del 2000, se aplicaron los tratamientos de mantenimiento; 5 áreas fueron quemadas y cinco se trataron con el aereador por segunda vez. Se estimó la producción de biomasa, valor nutricional, y concentración de taninos en la vegetación ramoneable por los venados. Se contaron las huellas de los venados en las áreas reastreadas alrededor de cada tratamiento para estimar el uso. La producción de forraje de los arbustos, herbáceas, zacates, y suculentas, concentración de taninos ligados a proteína en el ramoneo, y la densidad de huellas, no difirieron entre tratamientos. En base a la utilización de las areas por los venados, y la respuesta de la vegetación en producción de forraje, la quema prescrita y un segundo tratamiento de aereación 16 o 17 meses después del tratamiento inicial tienen un efecto similar en las características del habitat y la utilización de las áreas tratadas por el venado. Sin embargo, se recomienda la quema prescrita como tratamiento de mantenimiento para áreas aereadas debido a que es un tratamiento más económico.

digestibility than older, mature stands of vegetation (Everitt 1983, Reynolds et al. 1992), and are preferred by white-tailed deer over mature plants for browsing (Powell and Box 1966, Bozzo et al. 1992a). Top removal of brush also temporarily increases forb biomass (Rollins et al. 1988, Bozzo et al. 1992b). Deer prefer forbs over browse and grass (Chamrad and Box 1968, Bryant et al. 1981); however, woody plants are an important alternative forage source when availability of forbs is low, e.g., during drought conditions (Arnold and Drawe 1979).

Mechanical top removal treatments such as aeration have a short treatment life of 2-3 years and must be followed by 'maintenance' treatments to sustain increased availability and nutrition- 
al quality of browse and forbs and reduced woody canopy cover (Scifres 1980). However, it is unclear whether additional mechanical treatments or prescribed fire are preferable as maintenance treatments. Additional mechanical treatments may increase tannins in certain shrub species (Schindler 2000). Consumption of tannincontaining forage decreases the digestion of proteins and other nutrients (Hagerman et al. 1992).

White-tailed deer concentrate feeding activities in mechanically-cleared patches within shrub communities (Stewart et al. 2000). Increased forbs attract white-tailed deer to clearings (Rollins et al. 1988). Shrub sprouts also attract white-tailed deer and concentrate their feeding activities in clearings, particularly when low rainfall results in reduced forb availability (Stewart et al. 2000).

Mechanical aerators consist of large metal drums pulled by tractors and were originally designed for pasture aeration, i.e., reducing soil compaction and increasing water infiltration. Large aerators equipped with series of blades measuring $15 \times 15 \mathrm{~cm}$ mounted on each drum are increasingly being used for brush topgrowth removal. Aerators used on rangeland are similar to roller choppers, except that roller choppers have blades extending the entire width of the drum and mounted parallel to drum's axis, rather than individual blades. Mechanical aeration suppresses brush while leaving grass cover and promoting water infiltration because the blades create pits in the soil surface (Hanselka et al. 1993). Conversely, late summer prescribed burning removes grass cover, and may result in greater establishment of forbs (Ruthven and Synatzske 2002). Mechanically aerated plots maintained with late summer burns may temporarily have lower tannins in browse and more forbs, providing higher-quality forage for white-tailed deer than plots maintained with additional mechanical aeration.

We tested the predictions that (1) forbs will dominate aerated plots receiving prescribed fire as a maintenance treatment, while grasses will dominate plots receiving a second aeration as a maintenance treatment; (2) tannins will be lower in browse from burned plots than in browse from aerated plots; and (3) the greater availability of forbs and lower tannins in browse in burned-aerated plots will result in greater use of burned plots by whitetailed deer than use of twice aerated plots. To test our predictions, we determined (1) standing crop of selected browse, forbs, grasses, and succulents; (2) tannin content of selected browse species, and (3) whitetailed deer utilization of aerated and burned plots and twice aerated plots. We also determined crude protein (CP), gross energy (GE), neutral detergent fiber (NDF), acid detergent fiber (ADF), and acid detergent lignin (ADL) of selected browse, forbs, grasses, and succulents; and woody plant density, canopy cover, and screening cover because these habitat characteristics may influence use of plots by white-tailed deer (Stewart et al. 2000).

\section{Materials and Methods}

\section{Study Area}

Field research was conducted at the Chaparral Wildlife Management area $\left(28^{\circ} 20^{\prime} \mathrm{N}, 99^{\circ} 25^{\prime} \mathrm{W}\right)$ in the western South Texas Plains. Climate is characterized by hot summers and mild winters with an average (1984-99) daily minimum winter (January) temperature of $7^{\circ} \mathrm{C}$, an average (1984-99) daily maximum summer (July) temperature of $38^{\circ} \mathrm{C}$ (Texas Parks and Wildlife Department, unpubl. data), and a growing season of 249 to 365 days (Stevens and Arriaga 1985). Average (1989-2001) annual precipitation is $53 \mathrm{~cm}$ with peaks occurring in late spring (May to June) and early fall (September to October) (Texas Parks and Wildlife Department, unpubl. data, 2002) (Fig. 1).

Soils consist of Duval fine sandy loam, Duval loamy fine sand, and Dilley fine sandy loam (Stevens and Arriaga 1985 , Gabriel et al. 1994). The Duval series are fine loamy, mixed hyperthermic Aridic
Haplustalfs, and the Dilley series are loamy, mixed, hyperthermic shallow Ustalfic Haplargrids. Topography is nearly level to gently sloping and elevation ranges between 168 and $180 \mathrm{~m}$.

Plant communities are characteristic of the mesquite (Prosopis glandulosa Torr.) -granjeno (Celtis pallida Torr.) association (McLendon 1991). Within this association are 2 primary communities, the mesquite-colima (Zanthoxylem fagara (L.) Sarg.)- granjeno community, in which colima and bluewood brasil (Condalia hookeri M. C. Johnst.) are the sub-dominants, and the mesquite-granjeno-hog-plum (Colubrina texensis [T. \& G.] Gray) community, in which hog-plum is the subdominant. Prominent herbaceous species include Lehmann lovegrass (Eragrostis lehmanniana Nees), an introduced perennial, hooded windmillgrass (Chloris cucullata Bisch.), hairy grama (Bouteloua hirsuta Lag.), partridge pea (Chamaecrista fasciculata [Michx.] Greene), and various species of Croton. Common and scientific names follow Hatch et al. (1990).

The study area consists of 6,154 ha and is bordered by a $2.4 \mathrm{~m}$ woven-wire fence. Deer densities (1997-01) average 12 ha/deer based on results from helicopter surveys. There is minimal human presence during most of the year. Limited public hunting is allowed on the area in the fall and winter.

\section{Grazing History}

Domestic livestock have grazed the study area since the $18^{\text {th }}$ century (Lehmann 1969). Cattle were the major species of
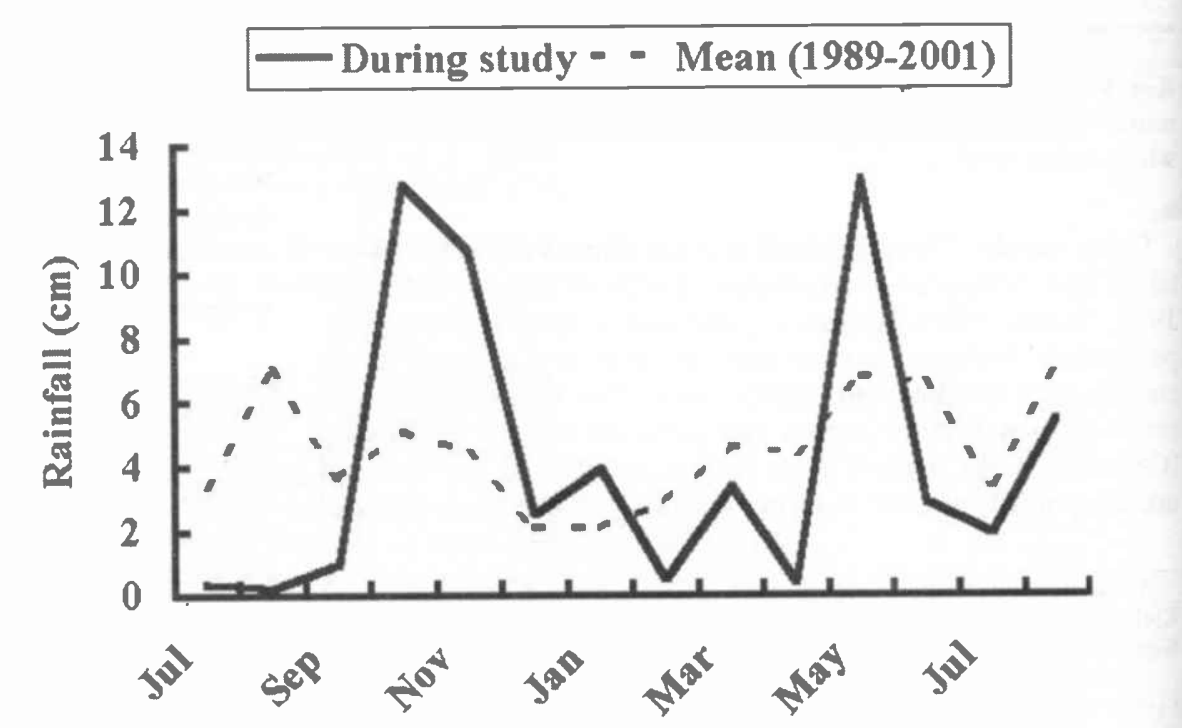

Fig. 1. Monthly rainfall during the study period (2000-2001) and 1989-99 average monthly rainfall (cm) for the Chaparral Wildlife Management Area, Dimmit County, Tex. 
livestock since about 1870 , whereas sheep were grazed from about 1750-1870. Before 1969 , grazing by cattle was continuous yearlong (G. Light, pers. commun., 1997). From 1969-1984 cattle (cow/calf) grazed yearlong, utilizing a 4-pasture rotation system. Cattle were absent from the area from 1984 to 1989. Cattle grazing resumed in 1990 and continued through 2001 utilizing a high-intensity, low frequency grazing system in which 2 separate herds were rotated once through 6 pastures during October through April. Stocking rates ranged from 13-23 animal unit days (AUD)/ha/yr during 1990 to 1998. During the study (1999-2001), stocking rate was 21-23 AUD/ha/yr. Cattle were removed from the study area 5 months before data were collected. Cattle were absent from the study area during the first 2 sampling periods, and were present during the final 2 periods.

\section{Experimental Design}

A single pass of a double-drum (drum sizes $=3.7 \overline{\mathrm{x}} 0.8 \mathrm{~m}$ ) mechanical aerator pulled by a crawler tractor was used to clear 10 plots of brush during late March through early April 1999. The plots were meandering strips with lengths ranging from $0.6-1.7 \mathrm{~km}$, and widths of $55.8 \pm 0.7$ $\mathrm{m}(\mathrm{x} \pm \mathrm{SE})$. Plots ranged from 3-9.1 ha, with an average of $4.8 \pm 0.6$ ha in size. Plots varied in size because they were originally created as part of a habitat improvement plan.

A randomized, complete block experimental design was used in the study. The 10 study plots were paired into 5 blocks, based on similarities of plot size, soil type, and vegetation composition. Treatments (a second aeration or a prescribed burn) were assigned randomly to plots in each pair. We did not compare vegetation and deer use on plots that had not been cleared because effects of top-growth removal and burning on vegetation compared to untreated plots, and deer use of cleared versus untreated plots, are well documented (Ruthven et al. 2000, ?.003, Stewart et al. 2000). The second aeration was conducted during September 2000 with a single pass of a single-drum (drum sizes $=$ $2.4 \times 1.1 \mathrm{~m}$ ) aerator pulled by a crawler tractor.

Prescribed fires were conducted between 1300-1700 hours on 26 September 2000 . Five, $0.25-\mathrm{m}^{2}$ quadrats were placed randomly and clipped in each plot before burning to estimate fuel type, quantity, and moisture. Weather conditions (relative humidity, wind speed and direction, and air temperature), burning conditions (fuel type, quantity, and moisture), and fire intensity (rate of spread and flame height) were documented at each of the 5 burned plots.

Fuel was divided into 4 categories: (1) 1-hour fuels (standing and horizontal dry material $>0.6 \mathrm{~cm}$ in diameter), (2) green herbaceous material, (3) 10-hour fuels (standing and horizontal dry material $>0.6$ $\mathrm{cm}$ and $<2.5 \mathrm{~cm}$ in diameter), and (4) green woody materials (Masters and Engle 1994). Woody materials $>2.5 \mathrm{~cm}$ in diameter burn slowly and were not considered fuel. All 4 categories of fuel were weighed upon collection, dried at $40^{\circ} \mathrm{C}$ to constant mass, and weighed dry to determine fuel moisture and dry fuel load.

Byram's (1959) equation was used to measure fire intensity:

$$
I=h w r
$$

where $I=$ frontal fire intensity $(\mathrm{kW} / \mathrm{m}) ; h$ is heat of combustion $(\mathrm{kJ} / \mathrm{kg})$; w is fuel consumed $\left(\mathrm{kg} / \mathrm{m}^{2}\right)$; and $r$ is rate of spread ( $\mathrm{m} / \mathrm{second}$ ).

After the prescribed burns, 5 randomly placed $0.25-\mathrm{m}^{2}$ frames were used to estimate residual fuel mass. Residual fuel was weighed, dried, and re-weighed to determine fire consumption. The rate of spread was estimated by timing the headfire over three, $10-\mathrm{m}$ intervals marked with $1.8 \mathrm{~m}$ metal t-posts.

\section{Biomass Estimation}

Biomass was estimated by double sampling all green, living material (from ground level to a height of $1.5 \mathrm{~m}$ ) of deer

Table 1. Shrub species included as deer browse in biomass samples from aerated plots, Dimmit County, Tex., 2000-2001.

\begin{tabular}{ll}
\hline \hline Common name & Scientific name \\
\hline allthorn & Koeberlinia spinosa Zucc. \\
Berlandier wolfberry & Lycium berlandieri Dunal \\
blackbrush acacia & Acacia rigidula Benth. \\
border paloverde & Parkinsonia texana (Gray) S. Wats. \\
brasil & Condalia hookeri M.C. Johnst. \\
capul & Schaefferia cuneifolia Gray \\
common beebush & Aloysia gratissima (Gill. \& Hook.) Troncoso \\
guajillo & Acacia berlandieri Benth. \\
guayacan & Guaiacum angustifolium Engelm. \\
honey mesquite & Prosopis glandulosa Torr. \\
huisache & Acacia smallii Isely \\
knifeleaf condalia & Condalia spathulata Gray \\
la coma & Bumelia celastrina Kunth in H.B.K. \\
lotebush & Ziziphus obtusifolia (T. \& G.) Gray \\
narrowleaf forestiera & Forestiera angustifolia Torr. \\
shrubby blue sage & Salvia ballotiflora Benth. \\
spiny hackberry, granjeno & Celtis pallida Torr. \\
Texas colubrina, hogplum & Colubrina texensis (T. \& G.) Gray \\
Texas kidneywood & Eysenhardtia texana Scheele \\
Texas persimmon & Diospyros texana Scheele \\
Texas silverleaf & Leucophylum fiutescens (Berl.) I. M. Johnst. \\
twisted acacia & Acacia schafnerri (S. Watts.) Herm. \\
vine ephedra & Ephedra antisyphilitica C. A. Meyer \\
\hline
\end{tabular}

browse (leaves and the outer $5 \mathrm{~cm}$ of terminal portions of non-lignified stems) and succulent species to ground level in $0.5 \mathrm{~m}^{2}$ quadrats (Bonham 1989, Stewart et al. 2000). All shrub species encountered were considered deer browse, except coyotillo (Karwinskia humboldtiana [Schult.] Zucc.), lantana (Lantana horrida H.B.K.), and leatherstem (Jatropha dioica Sesse ex. Cerv.) (Table 1). These species may be toxic to white-tailed deer (Everitt and Drawe 1993, Taylor et al. 1997). Forb and grass biomass (to ground level) were estimated in thirty, $0.25-\mathrm{m}^{2}$ quadrats within each block-treatment combination nested within the $0.5-\mathrm{m}^{2}$ quadrats used for estimating biomass. In each block-treatment combination, 3 quadrats were placed at random distances along each of 10 randomly placed transects. Ocular estimations of total biomass and species percentages of composition by mass were made for selected browse, forb, and succulent species in each quadrat. For grass biomass, only total biomass was estimated in each quadrat. After ocular estimations were made, 1/3 of quadrats were selected randomly and all selected browse, forbs, grass, and succulent biomass was clipped. After collection, samples were weighed within 2 hours to obtain wet weights, dried at $40^{\circ} \mathrm{C}$ to constant mass, and re-weighed to obtain dry weights.

\section{Testing For Grazing Effects}

Forty, 2.4 × 2.4 x $1.5 \mathrm{~m}$ exclosures were constructed to protect forage from grazing by cattle and deer. Four exclosures were 
placed randomly in every block-treatment combination in late January 2001 before cattle grazed study pastures. In August 2001 , one, $0.25-\mathrm{m}^{2}$ quadrat was placed in the center of each exclosure and $2 \mathrm{~m}$ outside each exclosure from a randomly selected side of each exclosure. Forb and grass biomass were clipped from a height of $1.5 \mathrm{~m}$ to ground level within quadrats, dried at $40^{\circ} \mathrm{C}$ to constant mass, and weighed to determine forb and grass biomass inside and outside of the exclosures within a treatment.

\section{Estimating Nutritional Quality of Forage Biomass}

Dried forage was ground in a Wiley mill through a 1-mm mesh screen and analyzed in duplicate to determine percent $\mathrm{CP}, \mathrm{ADF}$, NDF, ADL, and GE. Percent nitrogen (N) was determined by a LECO CHN-1000 Carbon Hydrogen Nitrogen Analyzer and $\mathrm{CP}$ was estimated by multiplying $\mathrm{N}$ by 6.25. Neutral detergent fiber, $A D F$, and ADL were quantified with an ANKOM Fiber Analyzer by sequential fiber analysis methods outlined in Goering and Van Soest (1970). Gross energy was determined by combusting samples in a Parr adiabatic bomb calorimeter.

\section{Estimating Tannin Content of \\ Selected Browse}

Samples of leaves and the outer $5 \mathrm{~cm}$ of terminal ends of non-lignified stems of 5 randomly selected individuals for each selected browse species encountered during biomass sampling were collected at each site for protein-precipitating tannin analysis. At each plant, samples were collected from randomly selected stems at a height of $1 \mathrm{~m}$, or the highest point on shrubs $<1 \mathrm{~m}$, in each of 4 cardinal directions. Samples were placed on dry ice, transported to an electric freezer, and later freeze-dried for 48-60 hours. Dried samples from each site were ground in a Wiley mill through a 1$\mathrm{mm}$ mesh screen and mixed into a composite sample for each site based on ocular estimates of percentage species composition by mass. A patented protein-precipitation method (Silber and Davitt 2000), adapted from the classical protein precipitation assay (Hagerman and Butler 1978, Martin and Martin 1982), was used to quantify protein-precipitating tannins.

\section{Estimating Woody Plant Density and Canopy Cover}

Ten randomly placed $20-\mathrm{m}$ transects were placed in each block-treatment combination to estimate canopy cover of woody species. Transects were located from random points perpendicular to the same permanently established baseline described in Biomass Estimation. Canopy of woody species was estimated with the line intercept method (Higgins et al. 1996). Density of woody plants was estimated by counting rooted plants in ten, 20 x 1.5-m plots.

\section{Estimating Concealment Cover}

A modified $1.5 \times 1.2-\mathrm{m}$ checkered profile board was used to estimate deer concealment cover (Griffith and Youtie 1988). The board was divided into 48 evenly sized squares. The profile board was placed at 15 and $30 \mathrm{~m}$ in both directions perpendicular ( 1 inside and 1 outside) to the edge of each cleared study plot from 10 randomly selected locations. The percentage of squares that could be seen by the observer was recorded and used to estimate percent deer concealment cover.

\section{Measuring Deer Utilization}

A track count lane ( $2.4 \mathrm{~m}$ wide) was created around the perimeter of each of the cleared plots by blading with a bulldozer. Tracks were counted for 3 consecutive days during each sampling period. Track lanes were smoothed before the late evening peak activity period of deer (1.5 hours before sunset) (Hood 1971). The following morning, track count lanes were walked after sunrise and total individual deer crossings were counted. Individual deer crossings of each track count lane were totaled for each plot and divided by the length of track count lane to obtain deer crossings $/ \mathrm{km}$. Deer crossings $/ \mathrm{km}$ was used as a measure of intensity of deer use for treated plots.

\section{Sampling Periods}

Selected browse, forb, grass, and succulent biomass; $\mathrm{CP}, \mathrm{GE}, \mathrm{NDF}, \mathrm{ADF}$, and ADL of forage biomass; tannin content of browse; woody plant canopy cover; woody plant density; concealment cover percentage for deer; and deer crossings $/ \mathrm{km}$ were estimated during late May-July 2000 before treatment application. Selected browse, forb, grass, and succulent biomass; selected browse, forb, grass, and succulent percent CP, NDF, ADF, ADL, and GE; tannin content of selected browse, and deer crossings/ $\mathrm{km}$ were estimated concurrently post-treatment during December 2000-January 2001 (winter), May 2001 (spring), and June-July 2001 (summer). Woody plant canopy cover, woody plant density, and concealment cover for deer were estimated once post- maintenance in July 2001. Forb and grass biomass inside and outside exclosures were estimated in August 2001.

\section{Statistical Analyses}

We used a randomized, complete block ANOVA with treatment (twice aerated, aerated and burned) as a fixed effect in SAS/STAT (SAS Inst. 1989) to analyze differences in pre-treatment means of the following dependent variables: selected browse, forb, grass, and succulent biomass; CP, GE, NDF, ADF, and ADL of forage biomass; tannin content of selected browse; woody plant density; woody plant canopy cover; deer concealment cover percentages for 15 and $30 \mathrm{~m}$ inside and outside from cleared plot edges; and deer crossings $/ \mathrm{km}$. Differences in means were analyzed using a randomized, complete block ANOVA with treatment (a second aeration or prescribed burn) as a fixed effect and sampling period as a repeated measures factor in SAS/STAT. Grazing effects, woody plant density, woody plant canopy cover, and deer concealment cover percentages at 15 and $30 \mathrm{~m}$ inside and outside from cleared plot edges were estimated once post-treatment and differences in means were analyzed using a randomized, complete block ANOVA with treatment (twice aerated, aerated and burned) as a fixed effect in SAS/STAT. P-values for difference of means within a sampling period were obtained by using KenwardRogers approximation (SAS Inst. 1989) in all instances when treatment means or sampling period $\mathrm{x}$ treatment interactions were significant $(P<0.05)$. If sampling period $\mathrm{x}$ treatment interactions were not significant $(P>0.05)$, then means of all 3 post-treatment sampling periods were averaged across sampling periods. If sampling period $\mathrm{x}$ treatment interactions were significant $(P<0.05)$, then means from each sampling period were analyzed independently.

\section{Results}

\section{Fire Intensity}

Plots burned for $36.2 \pm 2.7$ minutes $(n=$ 5). Air temperatures averaged $24.9 \pm 0.3^{\circ}$ $\mathrm{C}$, wind speed was $6.8 \pm 0.4 \mathrm{~km} / \mathrm{hour}$, and relative humidity averaged $27.8 \pm 0.5 \%$. Fires consumed $58 \pm 11 \%(0.59 \pm 0.18$ $\mathrm{kg} / \mathrm{m}^{2}$ ) of available fuels. Fire intensity averaged $805 \pm 205 \mathrm{~kW} / \mathrm{m}$. 
Table 2. Mean ( $\pm \mathrm{SE}$ ) biomass of selected browse, forbs, grass, and succulents on plots receiving aeration or burning as maintenance treatments 16-17 months following an initial aeration treatment, Dimmit County, Tex., 2000-2001.

\begin{tabular}{|c|c|c|c|c|c|}
\hline \multirow{2}{*}{\multicolumn{2}{|c|}{ Sampling date and plant class }} & Twice aerated & \multicolumn{2}{|c|}{ Aerated and burned } & \multirow[t]{2}{*}{$\mathrm{P}$-value } \\
\hline & $\bar{x}$ & SE & $\overline{\mathrm{x}}$ & SE & \\
\hline \multicolumn{6}{|c|}{ Pre-treatment $(n=5)$} \\
\hline Browse & 181 & 45 & 264 & 71 & 0.408 \\
\hline Forb & 159 & 38 & 155 & 18 & 0.920 \\
\hline Grass & 2,336 & 707 & 2,568 & 412 & 0.589 \\
\hline Succulent & 570 & 295 & 892 & 470 & 0.648 \\
\hline \multicolumn{6}{|c|}{ Post-treatment ${ }^{1}(n=15)$} \\
\hline Browse & 153 & 40 & 106 & 26 & 0.202 \\
\hline Forb & 754 & 179 & 604 & 98 & 0.317 \\
\hline Grass & 197 & 38 & 327 & 77 & 0.164 \\
\hline Succulent & 301 & 126 & 308 & 131 & 0.980 \\
\hline
\end{tabular}

\section{Forage Biomass}

Before maintenance treatments were applied, biomass of selected browses $(\mathrm{P}=$ $0.408)$, forbs $(P=0.920)$, grasses $(P=$ $0.589)$, and succulents $(P=0.648)$ did not differ significantly between aerated plots that received aeration as a maintenance treatment and aerated plots that received burning as a maintenance treatment (Table 2). After application of maintenance treatments, the sampling period $\mathrm{x}$ treatment interaction was not significant for selected browse $(P=0.731)$, forb $(P=0.312)$, grass $(P=0.164)$, and succulent $(P=0.140)$ species biomass. Mean biomass of selected browse, forb, grass, and succulent species, averaged across sampling dates, was similar $(\mathrm{P}=0.202, \mathrm{P}=0.317, \mathrm{P}=$ 0.164 , and $P=0.980$, respectively) between twice aerated plots and aerated and burned plots. Total forb and grass biomass inside exclosures $(3,962 \pm 572$ and $490 \pm 199 \mathrm{~kg} / \mathrm{ha}$, respectively) did not differ significantly from total forb and grass biomass outside exclosures $(2,498 \pm 249$ and $1,852 \pm 709 \mathrm{~kg} / \mathrm{ha}$, respectively) for twice aerated $(P=0.086$ and $P=0.214$, respectively) and aerated and burned (forbs: inside, 3,266 \pm 686 , outside 2,235 $\pm 391 \mathrm{~kg} / \mathrm{ha}, \mathrm{P}=0.385$; and grass: inside, $783 \pm 215$, outside $1,551 \pm 596, P=$ $0.639)$ plots.

\section{Nutritional Quality of Forage Biomass}

Before maintenance treatments, $\mathrm{CP}$ and GE of selected browse $(P=0.963, P=$ $0.382)$, grass $(P=0.620, P=0.785)$, and succulent species $(P=0.898, P=0.637)$ did not differ between aerated plots which received aeration as a maintenance treatment and aerated plots which received burning as a maintenance treatment (Table 3). Forb CP did not differ $(P=0.198)$ significant, thus means for each treatment

\section{Aerated+aerated}

were averaged across sampling periods. Percent CP for each forage class did not differ $(P>0.05)$ between twice aerated and aerated and burned plots (Table 3 ).

There were no sampling period $\mathrm{x}$ treatment interactions $(\mathrm{P}>0.05)$ for selected browse, forb, or grass GE $(\mathrm{P}=0.573, \mathrm{P}=$ $0.843, \mathrm{P}=0.716), \mathrm{ADF}(\mathrm{P}=0.319, \mathrm{P}=$ $0.088, \mathrm{P}=0.408)$, and ADL $(\mathrm{P}=0.459, \mathrm{P}$ $=0.881, \mathrm{P}=0.891)$. Averaged across sampling periods, selected browse, forb, and grass GE, ADF, and ADL did not differ among treatments $(\mathrm{P}>0.05)$.

There was no sampling period $\mathrm{x}$ treatment interaction for succulent GE ( $\mathrm{P}=$ $0.466)$, NDF $(P=0.114)$, and ADL $(P=$ 0.066). Averaged across sampling periods, there were no $(\mathrm{P}>0.05)$ differences between succulent GE, NDF, and ADL among treatments. There was a sampling period $\mathrm{x}$ treatment interaction $(\mathrm{P}=0.002)$ for succulent $\mathrm{ADF}$, and sampling periods were analyzed separately, with succulent ADF being lower $(P=0.002)$ in twice aerated plots than aerated and burned plots in summer 2001 (Table 4).

There was no sampling period $\mathrm{x}$ treatment interaction for selected browse NDF $(\mathrm{P}=0.406)$ and grass NDF $(\mathrm{P}=0.835)$. Averaged across sampling periods selected browse and grass NDF was similar (P > 0.05 ) among treatments (Table 3 ). There was a sampling period $\mathrm{x}$ treatment interaction $(P=0.008)$ for forb NDF. A separate analysis of means revealed lower $(\mathrm{P}=$ $0.012)$ NDF in twice aerated plots than in aerated and burned plots in summer 2001 (Table 4).

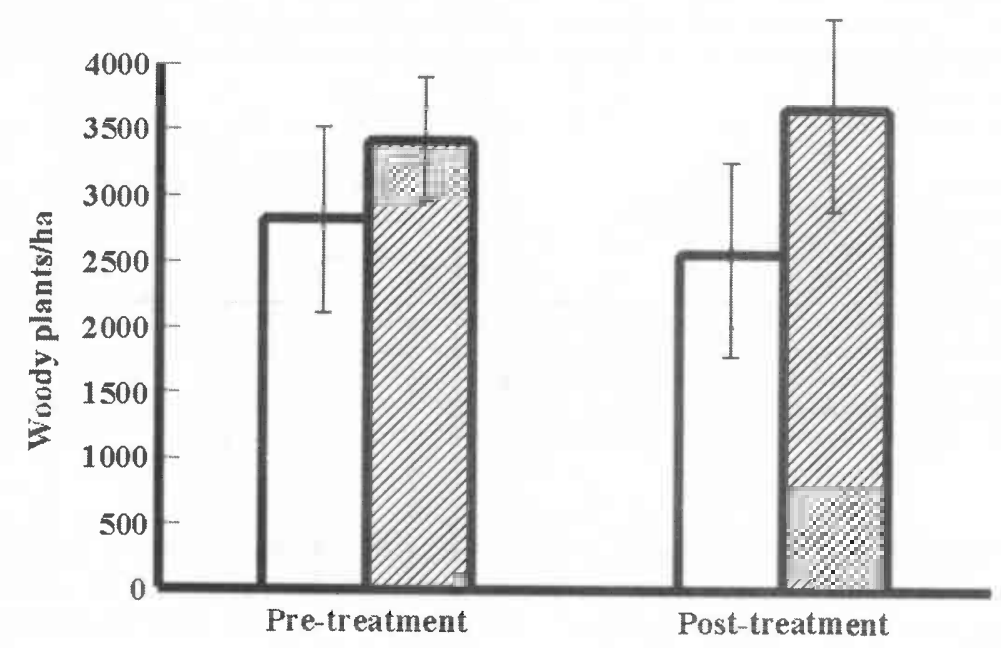

Aerated+burned

Fig. 2. Mean $( \pm S E)$ total woody plant density for aerated plots before $(n=5)$ and after $(n=$ 15) they were maintained 16-17 months later with a second aeration (open bars) or with a prescribed burn (cross-hatched bars), La Salle and Dimmit Counties, Tex., USA, 2000-2001. Means within a sampling period with the same letter are similar $(P>0.05)$. 
Table 3. Mean ( \pm SE) crude protein, gross energy, neutral detergent fiber, acid detergent fiber, and acid detergent lignin of selected browse, forbs, grass, and succulents on plots receiving aeration or burning as maintenance treatments 16-17 months following an initial aeration treatment, Dimmit County, Tex., 2000-2001.

\begin{tabular}{|c|c|c|c|c|c|}
\hline \multirow{2}{*}{$\begin{array}{l}\text { Sampling date, plant class, and } \\
\text { chemical component }\end{array}$} & \multicolumn{2}{|c|}{ Twice aerated } & \multicolumn{2}{|c|}{ Aerated and burned } & \multirow[t]{2}{*}{ P-value } \\
\hline & $\overline{\bar{x}}$ & $\mathrm{SE}$ & $\overline{\mathbf{x}}$ & $\mathrm{SE}$ & \\
\hline \multicolumn{6}{|l|}{ Pre-treatment $(n=5)$} \\
\hline \multicolumn{6}{|l|}{ Browse } \\
\hline Crude protein (\%) & 20 & $<1$ & 20 & 2 & 0.963 \\
\hline Gross energy $(\mathrm{cal} / \mathrm{g}$ ) & 4,733 & 144 & 4,873 & 19 & 0.382 \\
\hline Nuetral detergent fiber $(\%)$ & 32 & 2 & 35 & 1 & 0.307 \\
\hline Acid detergent fiber $(\%)$ & 21 & 1 & 26 & i & 0.024 \\
\hline Acid detergent lignin (\%) & 8 & 1 & 11 & 1 & 0.005 \\
\hline \multicolumn{6}{|l|}{ Forbs } \\
\hline Crude protein (\%) & 13 & 1 & 13 & 1 & 0.198 \\
\hline Gross energy (cal/g) & 4,370 & 77 & 4,297 & 81 & 0.034 \\
\hline Nuetral detergent fiber (\%) & 44 & 2 & 44 & 1 & 0.916 \\
\hline Acid detergent fiber $(\%)$ & 33 & 1 & 33 & 1 & 0.930 \\
\hline Acid detergent lignin (\%) & 6 & $<1$ & 7 & 1 & 0.056 \\
\hline \multicolumn{6}{|l|}{ Grasses } \\
\hline Crude protein (\%) & 9 & 1 & 8 & 1 & 0.620 \\
\hline Gross energy (cal/g) & 4,298 & 33 & 4,313 & 53 & 0.785 \\
\hline Nuetral detergent fiber (\%) & 72 & 2 & 71 & 1 & 0.272 \\
\hline Acid detergent fiber $(\%)$ & 41 & 1 & 40 & $<1$ & 0.384 \\
\hline Acid detergent lignin (\%) & 4 & $<1$ & 5 & 1 & 0.134 \\
\hline \multicolumn{6}{|l|}{ Succulents } \\
\hline Crude protein (\%) & 7 & 1 & 7 & 1 & 0.898 \\
\hline Gross energy (cal/g) & 3,068 & 239 & 3,312 & 57 & 0.637 \\
\hline Nuetral detergent fiber (\%) & 48 & 3 & 49 & $<1$ & 0.158 \\
\hline Acid detergent fiber (\%) & 29 & 4 & 23 & 3 & 0.751 \\
\hline Acid detergent lignin (\%) & 8 & $<1$ & 5 & 1 & 0.400 \\
\hline \multicolumn{6}{|l|}{ Post-treatment $(n=15)$} \\
\hline \multicolumn{6}{|l|}{ Browse } \\
\hline Crude protein (\%) & 20 & 1 & 21 & 1 & 0.289 \\
\hline Gross energy (cal/g) & 4,717 & 132 & 4,823 & 76 & 0.413 \\
\hline Nuetral detergent fiber $(\%)$ & 31 & 2 & 35 & 2 & 0.245 \\
\hline Acid detergent fiber (\%) & 22 & 2 & 27 & 2.3 & 0.258 \\
\hline Acid detergent lignin $(\%)$ & 8 & 1 & 10 & 1 & 0.513 \\
\hline \multicolumn{6}{|l|}{ Forbs $^{2}$} \\
\hline Crude protein $(\%)$ & 13 & 1 & 13 & 1 & 0.585 \\
\hline Gross energy (cal/g) & 4,247 & 129 & 4,112 & 138 & 0.129 \\
\hline Acid detergent fiber (\%) & 35 & 2 & 35 & 1 & 0.819 \\
\hline Acid detergent lignin $(\%)$ & 7 & $<1$ & 7 & $<1$ & 0.504 \\
\hline \multicolumn{6}{|l|}{ Grasses } \\
\hline Crude protein $(\%)$ & 10 & 1 & 10 & 1 & 0.584 \\
\hline Gross energy (cal/g) & 3,995 & 102 & 3,926 & 135 & 0.903 \\
\hline Nuetral detergent fiber (\%) & 69 & 2 & 69 & 2 & 0.990 \\
\hline Acid detergent fiber (\%) & 43 & 2 & 43 & 2 & 0.802 \\
\hline Acid detergent lignin $(\%)$ & 4 & $<1$ & 4 & $<1$ & 0.412 \\
\hline \multicolumn{6}{|l|}{ Succulents ${ }^{3}$} \\
\hline Crude protein (\%) & 6 & 1 & 9 & 2 & 0.166 \\
\hline Gross energy (cal/g) & 3,231 & 111 & 3,204 & 92 & 0.916 \\
\hline Nuetral detergent fiber $(\%)$ & 67 & 4 & 62 & 4 & 0.288 \\
\hline Acid detergent lignin (\%) & 4 & $<1$ & 5 & 1 & 0.233 \\
\hline
\end{tabular}

Sampling date $x$ treatment interactions were not significant $(P>0.05)$, so means were averaged across sampling dates. ${ }^{2}$ Sampling period $x$ treatment interactions was significant $(P<0.05)$ for forb NDF, so sampling periods were analyzed separately. Post-treatment forb NDF results are reported in Table 4.

${ }^{3}$ Sampling period $x$ treatment interaction was significant $(P<0.05)$ for succulent $A D F$, so sampling periods were analyzed separately. Post-treatment succulent ADF results are reported in Table 4.

\section{Tannin Content of Woody Plants}

Before maintenance treatments, proteinprecipitating tannins in composite browse samples did not differ between aerated plots to be aerated again and aerated plots to be burned $(27 \pm 8 \mathrm{mg} / \mathrm{g}$ and $55 \pm 20$ $\mathrm{mg} / \mathrm{g}$, respectively) before $(\mathrm{P}=0.122)$ or after $(P=0.387)(29 \pm 7$ and $23 \pm 5 \mathrm{mg} / \mathrm{g}$, respectively) maintenance treatments were applied. The sampling period $\mathrm{x}$ treatment interaction was not significant $(P=0.177)$ for composite browse after maintenance treatment application.

\section{Woody Plant Density, Canopy \\ Cover, and Concealment Cover}

Woody plant density and canopy cover were similar among twice aerated and aer- ated and burned plots before $(\mathrm{P}=0.152, \mathrm{P}$ $=0.311)$ and after $(P=0.169, P=0.422)$ treatment application (Figs. 2 and 3 ). Concealment cover at 15 and $30 \mathrm{~m}$ outside of the cleared plots was similar before $(\mathrm{P}=$ $0.712, P=0.474)$ and after $(P=0.102, P=$ 0.753 ) maintenance treatment application.

\section{Deer Utilization}

Deer crossings/km did not differ significantly between twice aerated plots and aerated and burned plots before ( $\mathrm{P}=$ $0.634)$ or after $(P=0.597)$ treatment application (Fig. 4). Following maintenance treatment application, the sampling period $\mathrm{X}$ treatment interaction was not significant $(P=0.860)$.

\section{Discussion}

The results of this study contradicted our prediction that grass biomass would be higher in twice aerated plots and that, conversely, forb biomass would be higher in aerated and burned plots. These results may be explained by the highly variable weather patterns during the study. During June-September 2000 the study area received $2.8 \mathrm{~cm}$ of rainfall compared to an average of $8.2 \mathrm{~cm}(1989-2001)$ (Texas Parks and Wildlife Department, unpublished data, 2002) (Fig. 1). Daily high temperatures during the July, August, and September preceding treatment applications averaged 41,39 , and $38^{\circ} \mathrm{C}$, respectively. These averages were 3,2 , and $4^{\circ} \mathrm{C}$ higher than average daily high temperatures for July, August, and September, respectively, during 1984-1999. The lack of rainfall coupled with abnormally high daytime temperatures appeared to result in high mortality of perennial grasses on the study site. Apparent perennial grass mortality on undisturbed rangeland adjacent to our study sites resulted in $91 \%$ lower grass biomass during summer 2001 than in summer 2000 (Rogers 2002), even though rainfall was near the long-term average in summer 2001. The Texas Agricultural Experiment Station in Sonora, about 250 $\mathrm{km}$ to the northwest of our study area, also reported similar high temperatures and drought conditions and subsequent mortality of perennial grasses during this period (R. Hinnant, pers. comm., 2002).

Fires conducted during summer had little effect on cool-season forbs. However, in previous research summer fires in the study area increased germination and establishment of warm-season annual forbs and certain perennial forbs, and resulted in short-term reductions in grass 
Table 4. Mean ( $\pm \mathrm{SE}, \boldsymbol{n}=5$ ) forb neutral detergent fiber and succulent acid detergent fiber on plots receiving aeration or burning as maintenance treatments 16-17 months following an initial aeration treatment, Dimmit County, Tex., 2000-2001.

\begin{tabular}{|c|c|c|c|c|c|}
\hline \multirow{2}{*}{$\begin{array}{l}\text { Plant class, chemical component, } \\
\text { and sampling date }\end{array}$} & \multicolumn{2}{|c|}{ Twice aerated } & \multicolumn{2}{|c|}{ Aerated and burned } & \multirow[t]{2}{*}{ P-value } \\
\hline & $\overline{\bar{x}}$ & SE & $\overline{\mathrm{x}}$ & SE & \\
\hline \multicolumn{6}{|l|}{ Forb neutral detergent fiber (\%) } \\
\hline Winter $2000-2001$ & 45 & 2 & 38 & 3 & 0.063 \\
\hline Spring 2001 & 51 & 2 & 48 & 2 & 0.399 \\
\hline Sumner 2001 & 38 & 3 & 47 & 2 & 0.012 \\
\hline \multicolumn{6}{|l|}{ Sueculent acid detergent fiber $(\%)$} \\
\hline Winter 2000-2001 & 24 & 4 & 33 & 3 & 0.062 \\
\hline Spring 2001 & 28 & 3 & 29 & 2 & 0.946 \\
\hline Summer 2001 & 37 & 4 & 23 & 3 & 0.002 \\
\hline
\end{tabular}

density (Ruthven and Synatzske 2002), whereas aeration increased grass and forb yield (Ruthven et al. 2000). We predicted that burning would favor forbs compared to $\cdot$ a second aeration because fire removes canopy cover of grasses, whereas aeration can leave much of the grass canopy intact. Removal of grass canopy by fire may give forbs a competitive advantage favoring their germination and establishment. However, grass mortality induced by drought and high temperatures may have ameliorated any treatment effect. The area received $9.3 \mathrm{~cm}$ of rainfall during October-November 2000 compared to the 1989-2001 average of $3.8 \mathrm{~cm}$. Abnormally high rainfall, coupled with a loss of perennial grass cover, likely resulted in the large increase in forb biomass in spring 2001 irrespective of maintenance treatment.

Lack of precipitation in summer and early fall 2000 may explain the similarity in woody plant canopy cover and density between treatments. Prescribed fire can reduce the cover and density of woody plants (Ruthven et al. 2003), whereas mechanical top removal treatments can increase stem density of woody plants and facilitate the quick recovery of woody plant canopies (Welch et al. 1985, Bozzo et al. 1992b). Drought stress at the time of the second aeration treatment may have increased mortality of woody plants or slowed their recovery rates resulting in similar amounts of cover on twice aerated and aerated and burned sites.

Application of aeration and burning as maintenance treatments to previously aerated rangeland sites in this study did not affect tannin content of woody plants. Increases in phenolic amines, another secondary metabolite, have been documented for 9 months after aeration of guajillo (Acacia berlandieri Benth.)-dominated sites in northeastern Mexico (Windels 1999). Our results were similar to (Schindler 2000) in which prescribed burning following mowing did not result in increased tannin concentrations in black- brush acacia (Acacia rigidula Benth.), mesquite, and granjeno 12 weeks posttreatment; however, tannins increased in blackbrush acacia 34 weeks after burning.

White-tailed deer did not exhibit an affinity for either treatment. Since both treat-

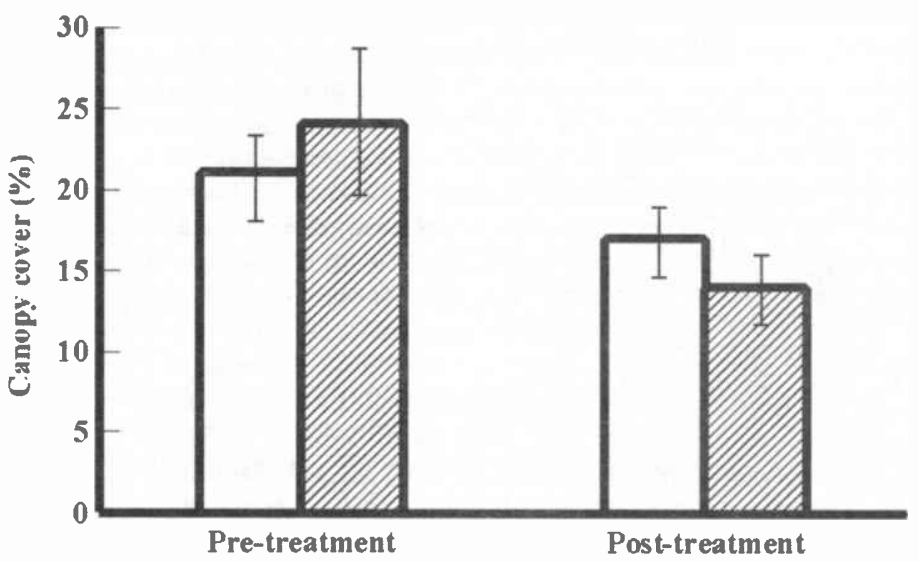

Fig. 3. Mean ( \pm SE) percentage of total woody plant canopy cover for aerated plots before ( $n$ $=5)$ and after $(n=15)$ they were maintained 16-17 months later with a second aeration (open bars) or with a prescribed burn (cross-hatched bars), Dimmit County, Tex, 2000-2001. Means within a sampling period with the same letter $\operatorname{are} \operatorname{similar}(P>0.05)$.

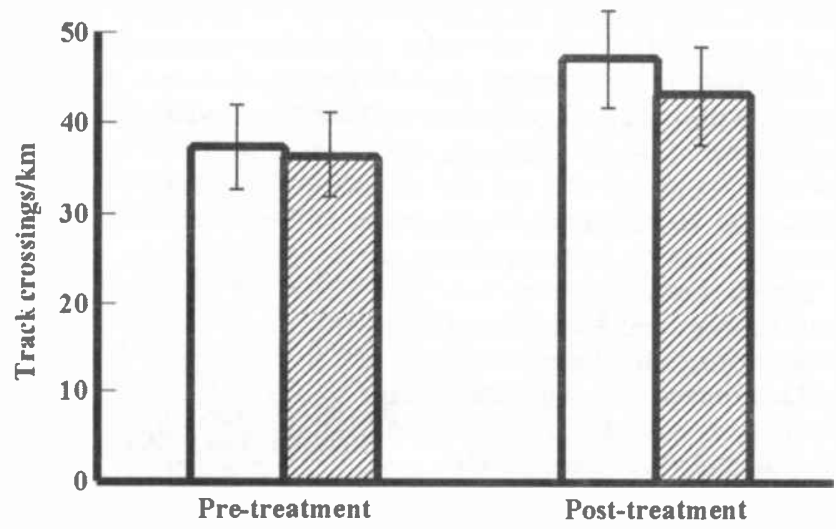

\section{Aerated+aerated Aerated+burned}

Fig. 4. Mean ( \pm SE) deer crossings $/ \mathrm{km}$ of track count lane for aerated plots before $(n=5)$ and after $(n=15)$ they were maintained 16-17 months later with a second aeration (open bars) orwith a prescribed burn (cross-hatched bars), Dimmit County, Tex., 2000-2001. Means within a sampling period with the same letter are similar $(P>0.05)$. 
and temperature patterns during this study clearly influenced results and underscore the importance of long-term research, particularly in semiarid regions such as south Texas that have extremely variable rainfall patterns and frequent periods of short-term drought (Norwine and Bingham 1985). Prescribed burning may be the most economical treatment to maintain mechanically-created openings on south Texas rangelands. The cost of the second aeration was $\$ 57-69 /$ ha compared to $\$ 7-12 /$ ha for burning (Texas Parks and Wildlife Department, unpublished data, 2002).

\section{Literature Cited}

Arnold, L.A. and D.L. Drawe. 1979. Seasonal food habits of white-tailed deer in the south Texas plains. J. Range Manage. 32:175-178.

Bonham, C.D. 1989. Measurements for terrestrial vegetation. John Wiley and Sons. New York, N. Y.

Bozzo, J.A., S.L. Beasom, and T.E. Fulbright. 1992a. White-tailed deer use of rangeland following browse rejuvenation. J. Range Manage. 45:496-499.

Bozzo, J. A., S.L. Beasom, and T.E. Fulbright. 1992b. Vegetation responses to two brush management practices in south Texas. J. Range Manage. 45:170-175.

Bryant, F.C., C.A. Taylor, and L.B. Merrill. 1981. White-tailed deer diets from pastures in excellent and poor range condition. J. Range Manage. 34:193-200.

Byram, G.M. 1959. Combustion of fine fuels, pages 61-89. In K.P. Davis (ed.) Forest fire: control and use. McGraw-Hill, New York, N.Y.

Chamrad, A.D. 1966. Winter and spring food habits of white-tailed deer on the Welder Wildlife Refuge. M. S. Thesis, Texas Tech Univ., Lubbock, Tex.

Chamrad, A.D. and T.W. Box. 1968. Food habits of white-tailed deer in South Texas. J. Range Manage. 21:153-164.

Everitt, J.H. 1983. Effects of shredding on nutrient content of four south Texas deer browse species. J. Range. Manage. 36:779-781.

Everitt, J.H. and D.L. Drawe. 1993. Trees, shrubs, and cacti of south Texas. Texas Tech Univ. Press. Lubbock, Tex.

Gabriel, W.J., D. Arriaga, and J.W. Stevens. 1994. Soil survey of La Salle County, Texas. USDA, U.S. Government Printing Office, Washington D. C.

Goering, H.K. and P.J. Van Soest. 1970. Forage fiber analysis (apparatus, reagents, procedures, and some applications). Agr. Handb. No. 379. ARS, USDA, U.S. Government Printing Office, Washington, D. C.

Griffith, B., and B. A. Youtie. 1988. Two devices for estimating foliage density and deer hiding cover. Wildl. Soc. Bull.16:206-210.
Hagerman, A.E. and L.G. Butler. 1978. Protein precipitation method for quantitative determination of tannins. Food Chem. 26:809-812.

Hagerman, A.E., C.T. Robbins, Y. Weerasuriya, T.C. Wilson, and C. McArthur. 1992. Tannin chemistry in relation to digestion. J. Range Manage. 45:57-62.

Hanselka, C.W., S.D. Livingston, and D. Bade. 1993. Renovation practices to improve rainfall effectiveness on rangeland and pastures. Tex. Agr. Ext. Serv. Publication no. L5077.

Hatch, S.L., K.C. Gandhi, and L.E. Brown. 1990. Checklist of the vascular plants of Texas. Tex. Agr. Exp. Stat. Report MP-1655. College Station, Tex.

Higgins, K.F., J.L. Oldemeyer, K. J. Jenkins, G. K. Clambey, and R. F. Harlow. 1996. Vegetation sampling and measurement, pages 567-591. In: T. Bookhout, (ed.) Research and management techniques for wildlife and habitats. Fifth ed. Rev. The Wild. Soc., Bethesda, Md.

Hood, R.E., 1971. Seasonal variations in home range, diel movements and activity patterns of white-tailed deer on the Rob and Bessie Welder Wildlife Refuge, M. S. Thesis. Texas A\&M Univ., College Station, Tex.

Lehmann, V.W. 1969. Forgotten legions: sheep in the Rio Grande Plain of Texas. Texas Western Press, El Paso, Tex.

Martin, J.S. and M.M. Martin. 1982. Tannin assays in ecological studies: Lack of correlation between phenolics, proanthocyanidins, and protein-precipitating constituents in mature foliage of six oak species. Oecologia 54:205-211.

Masters, R.M. and D.M. Engle. 1994. BEHAVE- evaluated for prescribed fire planning in mountainous oak-shortleaf pine habitats. Wildl. Soc. Bull. 22:184-191.

McLendon, T. 1991. Preliminary description of the vegetation of south Texas exclusive of coastal saline zones. Tex. J. Sci. 43:13-32.

McMahan, C.A. and J.M. Inglis. 1974. Use of Rio Grande Plain brush types by whitetailed deer. J. Range Manage. 27:369-374.

Norwine, J., and R. Bingham. 1985. Frequency and severity of drought in south Texas, p. 1-19. In: R. Brown (ed) Livestock and wildlife management during drought. Caesar Kleberg Wildl. Res. Inst., Kingsville, Tex.

Powell, J. and T. W. Box. 1966. Brush management influences preference values of south Texas woody species for deer and cattle. J. Range Manage. 19:212-214.

Reynolds, J.P., T.E. Fulbright, and S.L. Beasom. 1992. Mechanical rejuvenation to dampen seasonal variation in chemical composition of browse. J. Range Manage. 45: 589-592.

Rogers, J.O. 2002. Vegetation regrowth and deer utilization of aerated plots after maintenance burning and re-aeration. M. S. Thesis, Texas A\&M University-Kingsville, Kingsville, Tex.
Rollins, D.C. and F.C. Bryant. 1986. Floral changes following mechanical brush removal on the Edwards Plateau of Texas. J. Range Manage. 39:237-240.

Rollins, D.C., F.C. Bryant, D.D. Waid, and L. C. Bradley. 1988. Deer response to brush management in central Texas. Wildl. Soc. Bull. 16:277-284.

Ruthven, D.C., III and D.R. Synatzske. 2002. Response of herbaceous vegetation to summer fire in the western south Texas plains. Tex. J. Sci. 54: In press.

Ruthven, D.C., III, D.R. Rios, and A.G. Gandaria. 2000. Response of herbaceous vegetation to aeration of a blackbrush-gajillo community. Tex. J. Agr. Nat. Res. 13:51-60.

Ruthven, D.C., III, A.W. Braden, H.J. Knutson, J.F. Gallagher, and D.R. Synatzske. 2003. Woody vegetation response to various burning regimes in south Texas. J. Range Manage. 56:In press.

SAS Institute, Inc. 1989. SAS user's guide: statistics. 1989 edition. SAS Institute, Inc., Cary, N.C.

Schindler, J.R. 2000. Role of spinescence and secondary compounds in white-tailed deer preference of shrubs in burned and mowed areas in south Texas. M. S. Thesis, Texas A\&M University-Kingsville, Kingsville, Tex.

Scifres, C.J. 1980. Brush management. Principles and practices for Texas and the Southwest. Texas A\&M Univ. Press, College Station, Tex.

Silber, M.L., and B. B. Davitt. 2000. Methods for preparation and use of a coomassie brilliant blue/protein complex. U.S. patent \# $6,057,160$.

Stewart, K.M., T.M. Fulbright, and D.L. Drawe. 2000. White-tailed deer use of clearings relative to forage availability. J. Wildl. Manage. 64:733-741.

Stevens, J.W. and D. Arriaga. 1985. Soil survey of Dimmit and Zavala counties, Texas. USDA, U.S. Government Printing Office, Washington, D.C.

Taylor, R.B., J. Rutledge, and J.G. Herrera. 1997. A field guide to common south Texas shrubs. Texas Parks and Wildife Press, Austin, Tex.

Walsh, P.B. 1985. Habitat use and population fluctuations of white-tailed deer at La Copita Research Area, Jim Wells County, Texas. M. S. Thesis, Texas A\&M Univ., College. Station, Tex..

Welch, T.G., R.P. Smith, and G.A. Rasmussen. 1985. Brush management technologies. Pages 15-24 in Integrated brush management systems for south Texas: development and implementation. Tex. Agr. Exp. Sta. Bull 1493, Tex. A\&M Univ., College Station, Tex.

Windels, S.K. 1999. Effects of roller chopping on white-tailed deer nutritional carrying capacity and habitat, and phenolic amine content of guajillo in northeastern Mexico. M. S. Thesis, Texas A\&M Univ. at Kingsville, Kingsville, Tex. 